\title{
Spinal Cord, Spinal Root, and Brain MRI Abnormalities in Congenital Zika Syndrome
}

T

he recent article "Spectrum of Spinal Cord, Spinal Root, and Brain MRI Abnormalities in Congenital Zika Syndrome with and without Arthrogryposis" is very interesting. ${ }^{1}$ Aragao et $\mathrm{al}^{1}$ concluded that "Most infants had some degree of spinal cord thickness reduction, predominant in the thoracic segment (without arthrogryposis) or in the entire spinal cord (with arthrogryposis)." We would like to share ideas and observations from tropical Asia, where the Zika virus infection is also endemic. Although the neurologic defect is common in the affected infants in tropical America, it is rarely seen among the affected infants in tropical Asia. ${ }^{2}$ Most affected cases in Southeast Asia are asymptomatic, and there is no abnormality in spinal or brain MR imaging. ${ }^{3}$

\section{REFERENCES}

1. Aragao MFVV, Brainer-Lima AM, Holanda AC, et al. Spectrum of spinal cord, spinal root, and brain MRI abnormalities in congenital Zika syndrome with and without arthrogryposis. AJNR Am J Neuroradiol 2017 Mar 31. [Epub ahead of print] CrossRef Medline

2. Wiwanitkit $S$, Wiwanitkit $\mathrm{V}$. Afebrile, asymptomatic and non-thrombocytopenic Zika virus infection: don't miss it! Asian Pac J Trop Med 2016;9:513 CrossRef Medline

3. Joob B, Wiwanitkit V. Fetal magnetic resonance imaging of fetus with Zika virus infection. Pediatr Neurol 2017;68:e1 CrossRef Medline

(1)B. Joob Sanitation 1 Medical Academic Center Bangkok, Thailand (D) V. Wiwanitkit Hainan Medical University

http://dx.doi.org/10.3174/ajnr.A5268 